\title{
Distribution and Ecological Range of the Alien Plant Species Mikania micrantha Kunth (Asteraceae) in Taiwan
}

\author{
Willis, Maja', Stefan Zerbe ${ }^{2 \star}$ and Yau-Lun Kuo ${ }^{3}$ \\ ${ }^{1}$ Institute of Ecology, Berlin University of Technology, Rothenburgstrasse 12, D-12165 Berlin, Germany \\ ${ }^{2}$ Institute of Botany and Landscape Ecology, University of Greifswald, Grimmer Strasse 88, D-17487 Greifswald, Germany \\ ${ }^{3}$ Department of Forestry, National Pingtung University of Science and Technology, No. 1 HsuehFu Rd., \\ 91201 Neipu, Pingtung, Taiwan
}

\begin{abstract}
In the past two decades Mikania micrantha Kunth, a climbing plant species originating from tropical America, has spread across Taiwan. It can now be found frequently in the lowlands and lower mountain areas up to $1,000 \mathrm{~m}$ a.s.l. in the centre and south of the island. Mikania micrantha is considered a problematic invasive alien plant species which is said to cause economical as well as environmental damage. This study investigated the ecological site characteristics of $M$. micrantha in Taiwan. 112 vegetation surveys were carried out in habitats where the alien plant was present. A comparison between sites with a high and a low abundance was carried out in order to assess which factors especially influence the extensive spread of the plant. Furthermore, the influence of disturbances was examined. Results showed that Mikania micrantha grows very dense in habitats which are characterized by good light conditions combined with vertical structures, such as trees. Results revealed that this invader occurs most frequently in agricultural fallows and wastelands, but it could hardly be found in the intensively managed plantations in the investigation area. Results provide great evidence that the plant is strongly influenced by disturbances, but only if impacts occur rarely.
\end{abstract}

Key words: Alien plant species, Biological invasions, Disturbance, Land abandonment, Land use

\section{INTRODUCTION}

The impacts of biological invasions by alien species are today recognized as serious environmental and socio-economic problems worldwide (Pyšek et al. 1995, Cronk and Fuller 1995, Drake et al. 1989, Mooney and Hobbs 2000, GISP 2003, Nentwig 2008). There is abundant evidence that plant invasions can cause serious damage to the environment and the human society (e.g. IUCN 2000, Pimentel et al. 2000, Perrings et al. 2002, GISP 2003), but in some cases it is questionable whether an alien species really poses problems in its introduced range. Since a lot of money can be spent on control measures against invasive alien species (Starfinger et al. 2003), it should be carefully examined what kind of consequences emanate from the occurrence and spread of introduced plants in reality before large scale management programs are initiated.

Mikania micrantha Kunth, an herbaceous perennial climber of the family Asteraceae, originating from subtropical and tropical America (Holm et al. 1977) is today widespread in many subtropical and tropical Asian countries. Its non-native range stretches from India, where the plant was introduced on purpose during the Second World War (Parker 1972), to Indonesia, across the Pacific
Islands and to southern China (Waterhouse 1994, Zhang et al. 2004). The plant is reported to cause serious problems outside of its native geographic distribution, especially in agricultural and silvicultural systems of the moist tropics in Southeast Asia and the Pacific (Parker 1972, Waterhouse 1994). Today, it is considered one of the 100 worst invasive alien species in the world (GISD 2006).

Throughout its native range, M. micrantha is a common plant, but it is seldom considered a weed (Holm et al. 1977). It grows primarily in open and moist habitats, for example along streams or lake margins, on the edge of forests, in damp lowland clearings, and along roadsides (Holm et al. 1977, Holmes 1993). The plant occurs at elevations up to 2,000 m a.s.l. and it was even observed in high mountains growing at 3,000 $\mathrm{m}$ in Bolivia (Holm et al. 1977).

Mikania micrantha can reproduce generatively as well as vegetatively. It produces a large number of seeds (Kuo et al. 2002), which are easily dispersed by wind, but also in the hair of animals or in clothing (GISD 2006, PIER 2007). Seeds germinate especially well under light-intensive conditions and in disturbed areas (Kuo et al. 2003, Hsu and Chiang 2003, Hu and But 1994). Vegetative propagation can be considered at least as important as the reproduction by seeds (Holm et al. 1977, Hsu and Chiang 2003). Especially in

\footnotetext{
* Corresponding author; Phone: +49 (0)30-72291820, e-mail: zerbe@uni-greifswald.de
} 
areas with open soil, the American climber can develop stems across the ground which are similar to runners. Because of the plant's ability to regenerate from stem sections with only one node, control measures by cutting or mowing are problematic if the cut material is not removed properly (Holm et al. 1977). Mikania micrantha also has a strong ability to resprout from the base after being cut back (Kuo et al. 2003). The plant can climb up to more than $15 \mathrm{~m}$ in height (Holm 1993, Zhang et al. 2004), supporting itself in other vegetation or any kind of vertical structure. It has the ability to develop dense carpets on top of other plants, effectively smothering them from light and thus negatively affecting their growth (e.g. Holm et al. 1977, Huang et al. 2000b, Kuo et al. 2003).

Mikania micrantha is regarded as a pest in a great variety of agricultural and silvicultural production systems across Asia, especially in young plantations of perennial crops, such as tea, rubber, banana, oil palm, and teak (Parker 19972, Holm et al. 1977, Sankaran et al. 2001, Feng et al. 2002, Zhang et al. 2004, GISD 2006). It is reported that $M$. micrantha seriously damages different ecosystems by smothering other vegetation (Feng et al. 2002, Zhang et al. 2004), but few studies go into detail defining the actual consequences for the environment or the economy in the Chinese region (e.g. Sankaran et al. 2001).

According to Chiang et al. (2002), the first occurrence of $M$. micrantha in Taiwan was recorded in 1986 in Wan Luan, Pingtung County. In Taiwan, the alien plant is commonly found on abandoned land, in rarely managed orchards and betel nut plantations, in forest clearings, along the edge of forests and along roadsides (Hwang et al. 2003). Mikania micrantha is reported to seriously damage young tree plantations and orchards (Kuo et al. 2003) and it is considered as a threat to the native flora (Hwang et al. 2003). In order to control a further spread of the American climber on the island a lot of resources have been invested by governmental as well as civil conservation organizations (Kuo et al. 2003).

The objective of this study is to identify the ecological characteristics of M. micrantha habitats in Taiwan. The question whether there are differences between habitats where the plant occurs frequently and habitats where the plant occurs less frequently was addressed. The study aimed to find out those driving factors, which especially contribute to a high or low abundance of the climber. In this context, it was investigated whether the alien plant occurs with high densities in certain land-use types or vegetation formations, and if $M$. micrantha prefers certain soil conditions. By looking at these two parameters, the questions whether the plant favors certain light conditions, and if it is influenced by the soil moisture regime were indirectly taken into consideration. Further, it was assessed whether there is a correlation between disturbances, particularly human-induced disturbances, and the extensive spread of $M$. micrantha.

This study tested four hypotheses: (1) In Taiwan, M. micrantha prefers sites with good light conditions and, therefore, preferably occurs in more open habitats. The plant does not invade dense forest stands. (2) The American climber can be found frequently in anthropogenically influenced habitats and disturbances further the establishment and spread of M. micrantha. (3) The alien species is especially abundant on land, which has been subject to disturbances in the past, but is currently not used, for example agricultural fallows and wastelands. (4) The plant has an increased competitive ability on sites with a good moisture regime.

This study assessed, which habitats or land-use types are potentially at a higher risk to be invaded by the climber. Consequently, the work at hand contributes to the knowledge about the ecology of $M$. micrantha in Taiwan. A better understanding of the ecology of the plant is very important for the development and performance of effective control measures.

\section{MATERIALS AND METHODS}

\section{Study Area}

The study area is situated in the south-western lowlands of Taiwan (R.O.C.), in northern Pingtung County ( $22^{\circ} 37^{\prime} \mathrm{N}, 120^{\circ} 35^{\prime} \mathrm{E}$ ). The climate is tropical with a mean annual temperature of $24.7^{\circ} \mathrm{C}$ and a mean annual precipitation of 2,540 mm (Central Weather Bureau, Taiwan 1998 2006; data retrieved for Kaohsiung County, since Pingtung County does not have a weather station). The summer months are characterized by south-western monsoon, which brings thunderstorms and typhoons with heavy rainfall, often causing flooding (Geography of Taiwan 2001). About 80\% of the annual precipitation falls during the summer, while winters are dry (ibid.).

The landscape of the study area is primarily characterized by lowlands, which are bounded by the DaWu Mountain range to the east. Although DaWu Mountain rises up to 3,000 m a.s.l., the study area comprises only the lower mountains, which are below $1,000 \mathrm{~m}$.

The study area is strongly influenced by human activities and today agriculture and settlements characterize the landscape. The original vegetation has almost completely been destroyed, only few remnants of natural forest, mainly Ficus-Machilus forests, can still be found in rugged terrain or protected sites (Hsieh and Yang 1994). Small patches of secondary forest, often predominated by Macaranga tanarius and Broussonetia papyrifera, occur on abandoned lands. The major crop is the betel nut palm, but other perennial crops, such as pineapple, mango, lychee, longan, banana, papaya, guava, citrus, wax apple and coconut are also cultivated in large quantities. Other common land-use types in the area are forest plantations, 
agricultural fallows, and wastelands.

The region was chosen for this study since Pingtung County is one of the three counties of Taiwan with a high abundance of Mikania micrantha. Moreover, research about the American climber has already been conducted at the Department of Forestry, National Pingtung University of Science and Technology (NPUST), Pingtung County (Kuo et al. 2002, Kuo et al. 2003). NPUST campus was strategically suitable as a base for investigating a wide range of $M$. micrantha habitats. The main investigation area stretched about 12 $\mathrm{km}$ from north to south along the western edge of DaWu Mountain range and was approximately $4.5 \mathrm{~km}$ wide (Fig. 1). This area only encompassed habitats of the lowlands and hill regions. In order to cover a broader spectrum of M. micrantha habitats, further surveys were carried out in three locations outside the main investigation area. By this means, habitats along the foothills of the mountains, habitats of the lower mountain region, as well as habitats near to the coast were included in the investigations (Fig. 1).

\section{METHODS}

Field investigations in the study area were carried out from June to September 2006. The first work phase included a general survey

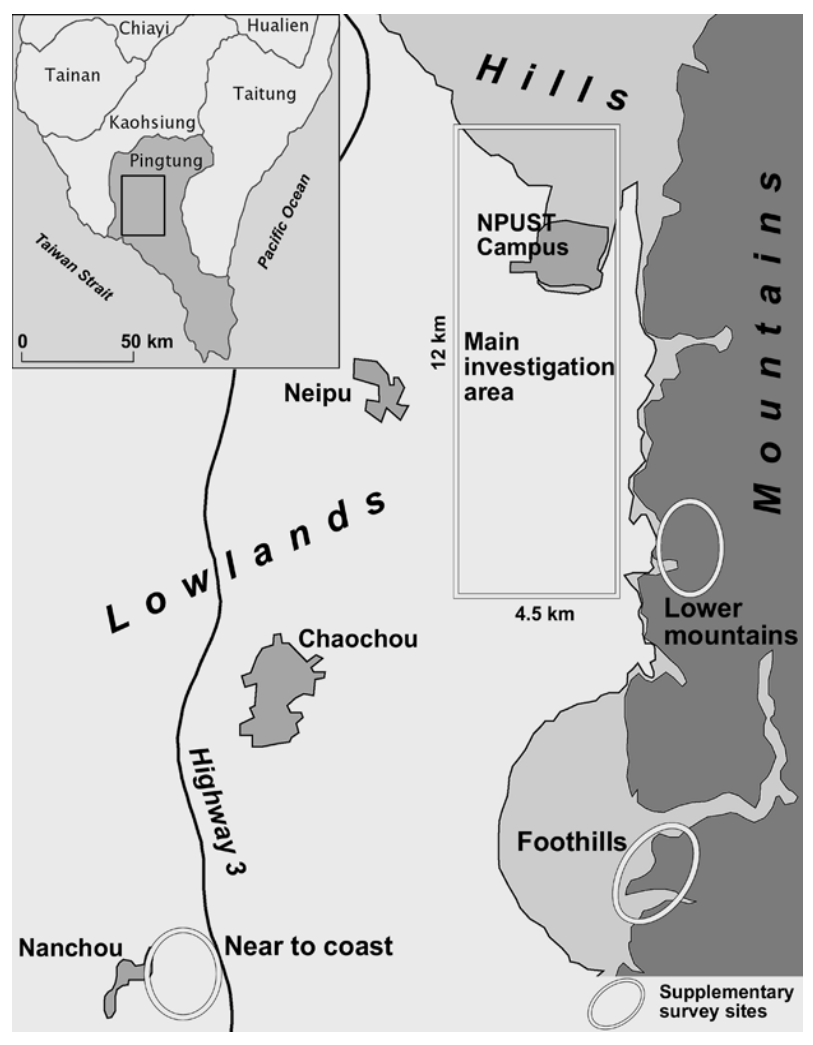

Fig. 1. Study area with main investigation area and three supplementary sites. of $M$. micrantha occurrences within the study area. Land use was broadly categorized following the biotope type mapping standards assembled by Knickrehm and Rommel (1995). Seven land-use types were distinguished: currently not used land (CNUL), managed green spaces (MGS), agricultural plantations (AP), agricultural tree plantations (ATP), forest (F), settlement (S) and water (W). Since $M$. micrantha also occurred along property boundaries (PB), along the edge of watercourses (WE) as well as along the edge of forests $(\mathrm{FE})$, these habitat types were treated as separate land use categories, although they do not represent land-use types of their own. Descriptions of all land-use categories can be found in Table 1.

\section{General Survey of Occurrences}

One main investigation area was chosen for collecting areacovering information about the distribution of $M$. micrantha as well as about the land use. In order to investigate a broader spectrum of $M$. micrantha habitats in the region, three additional areas outside the main investigation area were selected for conducting further vegetation surveys. Large-scale prints of aerial photographs (source: Agricultural and Forestry Aerial Survey Institute 1999 2002) served as working maps. Along with the recording of the occurrences of M. micrantha, its abundance was estimated in two grades: high (percent cover $>25 \%$ ) and low (percent cover $<25 \%$ ). The 25\% threshold was chosen according to Braun-Blanquet's (1964) cover values. Subsequently, a map with two layers, one containing vector data of the land use for the entire investigation area, and the other including vector data of all M. micrantha occurrences, was created using the GIS application ArcMap (ESRI). In order to systematically choose sites for the detailed vegetation surveys, a grid with cells representing approximately $400 \mathrm{~m} \times 400 \mathrm{~m}$ was placed on top of the map. It was demanded to carry out at least one vegetation survey in each grid cell where the alien species was present.

Due to restricted accessibility of private land, it was not possible to precisely record every single occurrence of $M$. micrantha, or identify the land-use type of $100 \%$ of all properties within the investigation area. However, the mapping covered about $80 \%$ of the M. micrantha sites and the land use (Appendix 1).

\section{Vegetation Analysis}

In a second step, detailed vegetation surveys, including an assessment of disturbances as well as the collection of soil samples, were carried out. The previously created map allowed a systematic selection of M. micrantha sites. Including the surveys outside the actual investigation area, a total of 112 sample plots were analyzed. The two M. micrantha abundance grades were represented as follows: 39 sites showed a low abundance of $M$. micrantha and 73 sites represented a high abundance of the invader. The size of the sample 
plots was $25 \mathrm{~m}^{2}$. All plant species within the sample plots were recorded and the percent cover was estimated following the method of Braun-Blanquet (1964, see also Mueller-Dombois and Ellenberg 1974). Plant specimens were identified according to Huang et al.
(1994) or with the help of the Provincial Pingtung Institute (PPI) herbarium at National Pingtung University of Science and Technology (NPUST). The nomenclature of species followed Huang et al. (1994). The mean cover percentage and the mean growth height

Table 1. Description of land-use categories / types

\begin{tabular}{lll}
\hline \hline \multicolumn{1}{c}{ Land-use category } & \multicolumn{1}{c}{ Habitat structure } & Management activities / disturbances \\
\hline Currently not used land (CNUL) & & \\
Agricultural fallows, abandoned orchards, aban- & Vegetation structure ranges from open (tree & Previously influenced by human activities, but \\
doned pineapple plantations, other former agri- & canopy very open, cover percentage $<5 \%$ ) to & not in use since several months to some years \\
cultural fields, abandoned grasslands, clearings & more closed formations (canopy cover $>35 \%$ ); & \\
inside of forests or within other tree dominated & shrub and tree succession, tall grass or herb & \\
formations, wastelands & communities characteristic & \\
\hline
\end{tabular}

Managed Green Spaces (MGS)

Habitats along roads, dykes along watercourses or around agricultural fields, parks and gardens, graveyards
Very diverse open grass or forb dominated formations to open shrub and tree formations
Management measures carried out at least twice a year; e.g. cutting or mowing, occasional application of herbicides

Agricultural Plantations (AP)

Agricultural land except for tree plantations, banana and papaya plantations
Usually very open; vegetation cover generally dominated by one single plant species
Management measures similar to those in agricultural tree plantations

Agricultural Tree Plantations (ATP)

Actively managed betel nut, betel nut-banana or betel nut-coconut plantations, fruit tree orchards, nursery plantations
Usually relatively open formations with little undergrowth, rarely dense herb layer
Management measures carried out at least twice a year, but usually more frequently; e.g. use of herbicides, cutting, mowing, harvesting

Forest (F)

Natural forests (secondary forests), silvicultu- Relatively closed canopy

Occasional maintenance of paths and roads ral plantations, bamboo groves

Settlement (S)

Settlements, industrial areas, single buildings

Percentage of sealed surfaces is above $80 \%$

Sealing of surfaces and military grounds

Water (W)

Artificial (e.g. fish ponds) and natural area-co- Water body

Weeding in and draining of artificial ponds; vering water surfaces, rivers water flow

Property Boundary (PB)

Linear habitats along fences

Good light conditions; herbaceous vegetation

Occasional application of herbicides predominant; usually many twining species

Forest edge (FE)

Habitats along the edge of secondary forests or silvicultural plantations

Usually well developed herbaceous layer; in some places shrubs
Rare to regular management measures, e.g. mowing or cutting

Watercourse edge (WE)

Mainly dykes along watercourse

Usually grass vegetation, but shrubs and trees also frequent; generally rather open; wet sites
Occasional disturbances by flooding; some areas managed by mowing 
Table 2. Characterization of disturbances

\begin{tabular}{ll}
\hline \hline \multicolumn{1}{c}{ Disturbance type } & \multicolumn{1}{c}{ Visual signs } \\
\hline Anthropogenic disturbances & Cut grass or branches \\
Mowing, cutting & Tracks on ground \\
Driving with vehicles & Dead plants among otherwise vital vegetation \\
Use of herbicides & Livestock \\
Grazing & Bare ground, tracks, dumped earth \\
Earth moving & $\begin{array}{l}\text { Presence of waste, e.g. household waste, } \\
\text { plastic items, rubble, earth or plant material }\end{array}$ \\
Dumping of waste & \\
\hline Natural disturbances & $\begin{array}{l}\text { Fallen trees, broken off tree branches } \\
\text { Natural death of trees } \\
\text { Wind }\end{array}$ \\
Flooding & $\begin{array}{l}\text { Uprooted vegetation and/or bare ground } \\
\text { along watercourse edge }\end{array}$ \\
\hline
\end{tabular}

for each vegetation layer (herb, shrub, and tree) were recorded. General information, including the coordinates of each site, slope inclination, habitat type, and land-use category, was collected.

The abundance of disturbances was assessed visually based on signs of management measures and natural impacts, which cause an opening of the vegetation (Table 2). Following this, the frequency with which disturbances influence a site (the history of impacts) was estimated. An important indicator for the disturbance frequency was the structure of the vegetation. According to the growth height of plants, especially of woody species, the disturbance frequency was rated either frequently or rarely. The third category abandonment included all land where currently no disturbances were noticed (Table 3).

\section{Soil Sampling and Analysis}

Soil samples were collected from $31 \mathrm{M}$. micrantha survey plots. Sites for the collection of soil samples were selected in a way that all possible combinations of soil types and land-use types of the area were represented. By studying soil maps (Taiwan Provincial Mountain Agriculture and Pasture Development Bureau 1984) prior to the investigations, a broad overview of the pattern of soil types in the study area could be gained. The distribution of soil types was then matched with that of the different land-use types. The soil samples were taken from the center of the plot area and comprised the upper $30 \mathrm{~cm}$ of soil.

All soil samples were air-dried and analyzed in the soil laboratory at the Department of Environmental Engineering, NPUST. The following soil parameters were determined: soil $\mathrm{pH}$, electric conductivity (EC), total nitrogen, organic carbon content, $\mathrm{C} / \mathrm{N}$ ratio and available phosphorous. Analysis methods were based on McLean (1982), Rhoades (1982), Keeney and Nelson (1982), Nelson and Sommers (1982), and Kuo (1996).

\section{Data Analysis}

In order to describe the habitat conditions of $M$. micrantha, the following parameters were taken into consideration: habitat and landuse type, vegetation formation, vegetation structure (mean cover percentage of the layers), occurrence of accompanying alien species, occurrence of indicators for soil moisture among the recorded plants, frequency of disturbances, and soil parameters. Certain parameters were determined as follows. All survey sites were assigned to three broad vegetation formation categories, i.e. tree, shrub, and herbaceous formation. This was based on the mean cover percentage of the layers. Tree formation comprised all sites where the mean cover percentage of the tree layer ( $>5 \mathrm{~m}$ ) exceeds $25 \%$, and shrub formation comprised all sites where the mean cover percentage of

Table 3. Classification of the disturbance frequency based on the vegetation structure

\begin{tabular}{|c|c|c|c|}
\hline Disturbance frequency & Vegetation structure & Frequency of management activities & Exemplary land-use types \\
\hline $\begin{array}{l}\text { Frequently } \\
\text { (= currently managed) }\end{array}$ & $\begin{array}{l}\text { Height of vegetation, esp. shrubs and } \\
\text { trees, low; open vegetation; herba- } \\
\text { ceous vegetation predominant }\end{array}$ & $\begin{array}{l}\text { Roughly every } 6 \text { months, in many } \\
\text { cases more frequently }\end{array}$ & $\begin{array}{l}\text { Managed agricultural and tree plan- } \\
\text { tations, gardens, parks, roadsides }\end{array}$ \\
\hline $\begin{array}{l}\text { Rarely } \\
\text { (= occasional measures) }\end{array}$ & $\begin{array}{l}\text { Height of vegetation, esp. shrubs and } \\
\text { trees, more developed; vegetation } \\
\text { more closed }\end{array}$ & Less than twice a year & $\begin{array}{l}\text { Managed agricultural and tree plan- } \\
\text { tations, gardens, parks, roadsides }\end{array}$ \\
\hline Abandonment & $\begin{array}{l}\text { Height of vegetation, esp. shrubs } \\
\text { and trees, more developed; vegeta- } \\
\text { tion more closed; high presence of } \\
\text { woody species }\end{array}$ & $\begin{array}{l}\text { Disturbance impacts in the past, } \\
\text { but currently not managed }\end{array}$ & Agricultural fallows, wastelands \\
\hline
\end{tabular}


the shrub layer $(1 \sim 5 \mathrm{~m})$ exceeds $25 \%$. The remaining sites belonged to herbaceous formation.

Information about the origin of species and their categorization as alien plants in Taiwan was gathered from Whiffin (1973), Morton (1987), Huang et al. (1993 2003), Wu et al. (2004), PIER (2007), Erhardt et al. (2000), Ng and Corlett (2002), Boufford et al. (2003), French et al. (2003), Silva et al. (2004), ISSG (2005), Danida Forest Seed Centre (2007), A Global Compendium of Weeds (2007), Federal Noxious Weed Disseminules of the U.S. (2007), eFloras (2007a,b), and NewCROP (2007).

Plant species were identified as indicators for soil moisture based on information of Huang et al. (1993 2003), PIER (2007), eFloras (2007a,b), Clayton et al. (2006 onwards), and USDA and NRCS (2007).

The habitat and land-use type, the mean cover percentage of the vegetation layers as well as the frequency of disturbances, were directly assessed in the field.

In a first step, all parameters were evaluated in order to characterize the site conditions of $M$. micrantha habitats in general. Secondly, it was assessed whether some parameters could be associated with a high abundance of this species. Therefore, all parameters were compared between the two $M$. micrantha abundance groups (group I = sites with high abundance, group II = sites with low abundance). Differences between the two groups were statistically analyzed with the SPSS program, applying the non-parametric Mann-Whitney U test.

\section{Differentiation of Site Conditions}

According to the methodology of Ellenberg et al. (2001), this analysis examined ecological characteristics of some of the plant species present in the M. micrantha habitats in order to obtain more information about the site conditions. The aim was to find out whether there are differences in the site conditions between habitats with a high and a low abundance of M. micrantha. Therefore, information about the ecological characteristics of such species, which showed a significant difference between the two M. micrantha abundance groups, was collected.

Ecological characteristics of these species included the preferred range of soil $\mathrm{pH}$, soil fertility, moisture requirements, tolerance of salinity, demand for light intensities, and vulnerability to disturbances. Information about the species was gathered from Holm et al. (1977), Duke (1983), Starr et al. (2003), ISSG (2005), Cook et al. (2005), PIER (2007), ICRAF (2007), and SANBI (2007).

\section{Comparison of Land-Use Types}

In order to find out whether M. micrantha is especially abundant in currently not used land, all land-use types were compared between areas where the plant is present and areas where it is absent.
Analyzing the vector map in ArcMap (comp. General Survey of Occurrences), the area coverage of each land-use type for the entire investigation area was calculated. The layer with M. micrantha occurrences was then intersected with that of the land use, obtaining information about the area coverage of land-use types for all areas with M. micrantha. Subsequently, the frequency of each land-use type was estimated for all areas where the American climber is present and all areas where it is absent.

\section{Analysis of the Disturbance Frequency}

At first, the percentage distribution of each of the three disturbance frequency categories was estimated. In a next step, the category abandonment was excluded and the frequency of the remaining categories, frequently and rarely, was assessed.

\section{RESULTS}

\section{Mikania micrantha Habitats}

Dense, area-covering occurrences of $M$. micrantha can rarely be found within the study area. If the plant colonizes larger areas, its abundance is usually low. In many cases, the American climber grows in small patches, forming linear or punctual populations.

In the investigation area, $M$. micrantha colonizes abandoned betel nut plantations, abandoned orchards and abandoned pineapple fields, as well as currently not managed grassland (with shrub or tree succession). Furthermore, the climber grows along the edge or in gaps of forest plantations, for example in Swietenia macrophylla, Calophyllum inophyllum, Araucaria spec., and Juniperus spec. or mixed species plantations, along the edge of bamboo groves, and secondary forests. In some cases, it can also be found within managed betel nut plantations, but it grows mainly along the fences around plantation properties (Fig. 2). M. micrantha often grows in

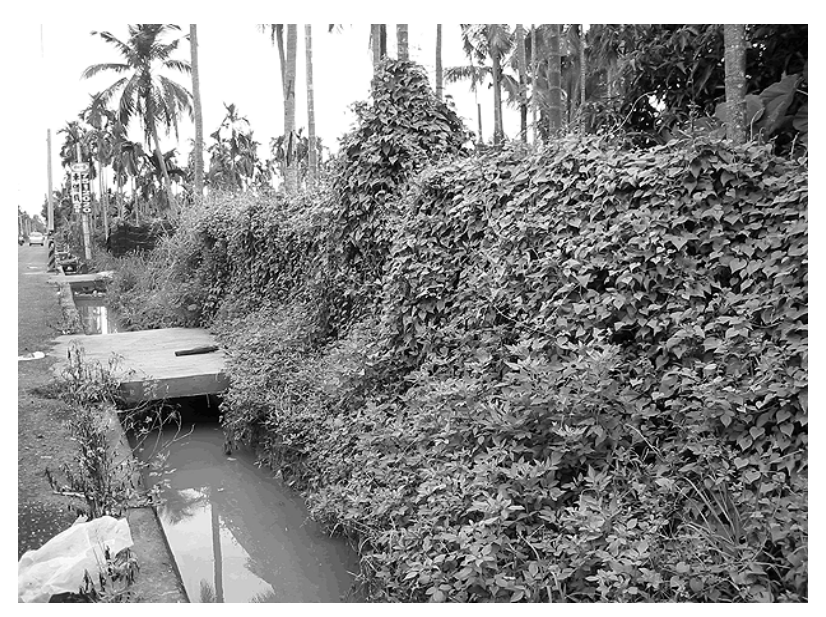

Fig. 2. Mikania micrantha habitat along fence. 
mango and wax apple orchards, which are currently managed. Wastelands, transitional areas between open grassland and tree formations and areas along watercourses and roadsides represent other frequent habitats of the plant.

\section{Parameters Determining $M$. micrantha Habitats}

\section{Land-Use Types}

The land-use type CNUL attains the highest frequency among all M. micrantha sample plots (45.5\%), the category MGS is second frequent (19.6\%), followed by PB (13.4\%) (Fig. 3). ATP, F, FE, and WE each account for less than $10 \%$. The comparison of the frequency of land-use types between areas where M. micrantha is present and areas where it is absent shows that the majority of landuse types in areas without the alien climber belongs to the category ATP and the majority of land-use types in areas with M. micrantha

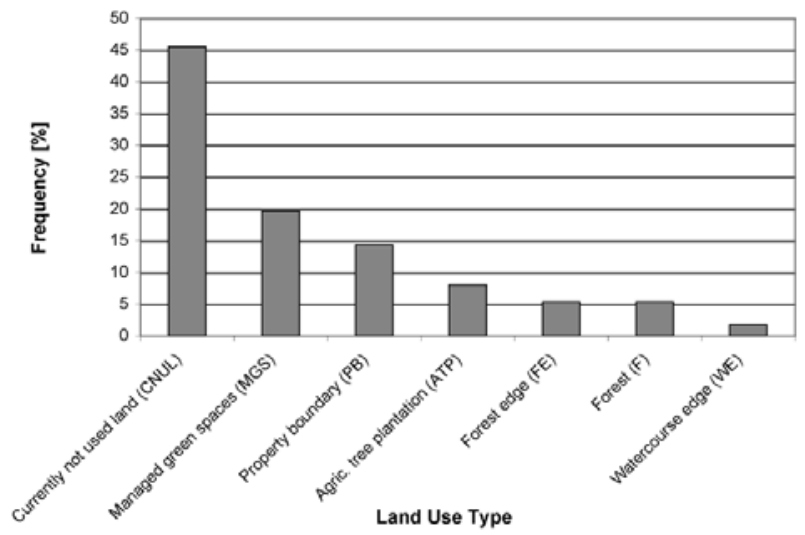

Fig. 3. Frequencies of land-use types among Mikania micrantha sample plots. belongs to CNUL (Fig. 4).

Comparing the frequency of land-use types between both $M$. micrantha abundance groups, percent values are very similar for the categories CNUL, MGS, ATP, and WE. Only the category PB attains a slightly higher percent value in group I and $\mathrm{F}$ as well as FE attain higher values in group II (Fig. 5).

\section{Vegetation Structure}

In general, $M$. micrantha occurs in relatively open habitats, as expressed in a relatively low mean cover percentage of the tree canopy (16\%). The undergrowth is generally well developed, although the mean cover percentage of the herb layer does not exceed $43 \%$. Even though high light supply in the habitat prevails, the vegetation formations are not completely open. Habitats are often diversely structured, which is represented by a mean cover percen-

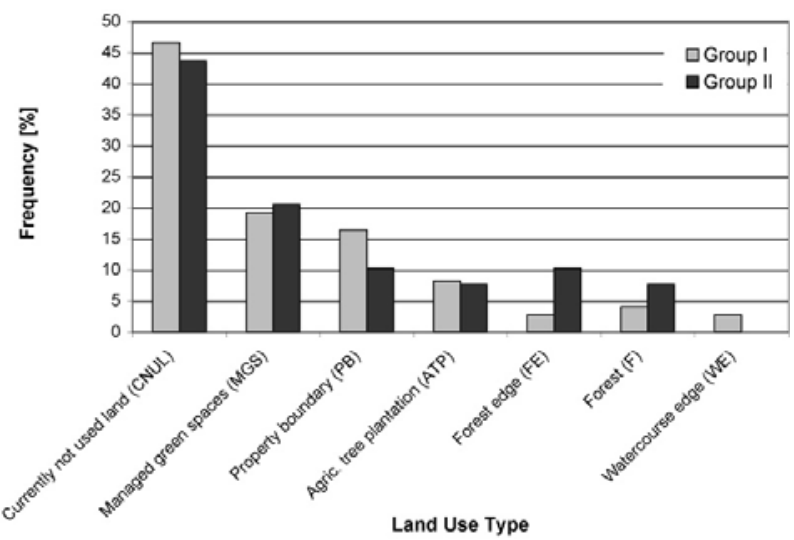

Fig. 5. Frequencies of land-use types within Mikania micrantha abundance groups (group I = high abundance, group II = low abundance of Mikania micrantha).
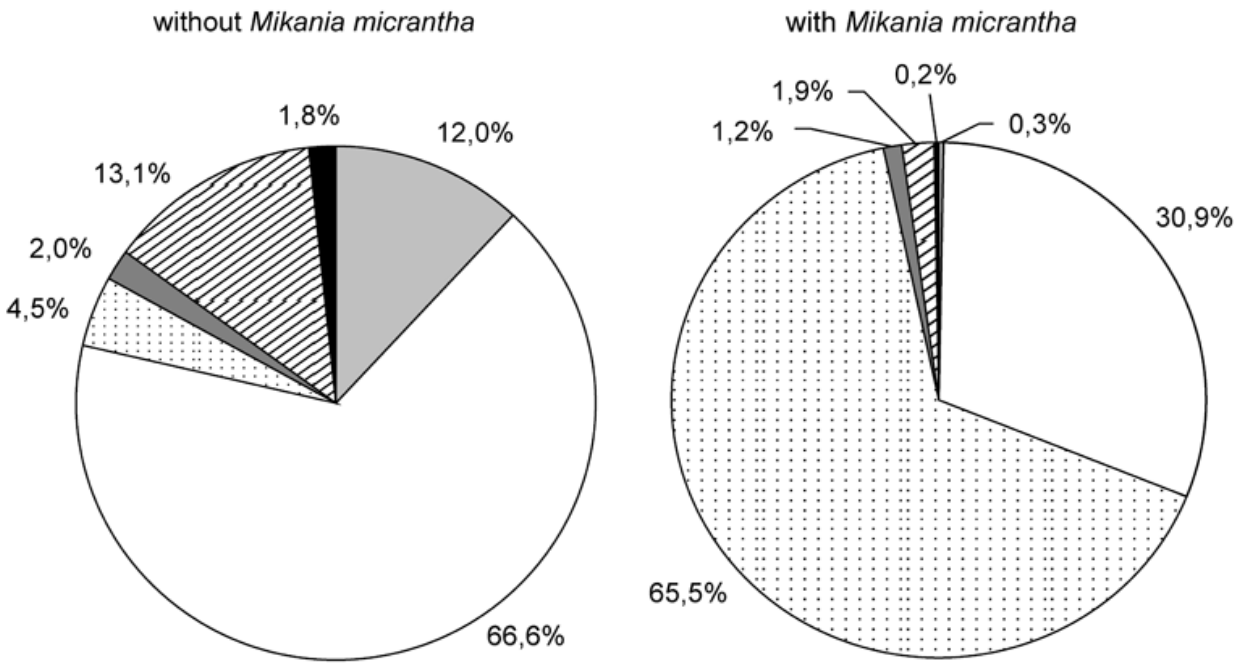

Agricultural plantation (AP)

Agricultural tree plantation (ATP)

. Currently not used land (CNUL)

$\square$ Managed green spaces (MGS)

$\square$ Settlement (S)

Water (W)

Fig. 4. Frequencies of land-use types in areas without and with Mikania micrantha. 
tage of $22 \%$ of the shrub layer.

The mean cover percentage of the tree, shrub, and herb layer is very similar in both $M$. micrantha abundance groups. The three layers were not significantly different between the two groups (Mann-Whitney $\mathrm{U}$ test; $p>0.08$ ). However, in those sites where the alien species occurs with a high abundance (group I) the coverage of the three layers is slightly lower (Fig. 6).

Regarding the three vegetation formations there is a significant difference between the two M. micrantha abundance groups (MannWhitney $\mathrm{U}$ test; $p<0.05)$. In group I, herbaceous formations are predominant (66\%), however, shrub formations still amount for $26 \%$. In group II, half of the sites constitute woody formations, which suggests that conditions are shadier here.

\section{Soil Parameters}

Box plot diagrams of data of all soil parameters are presented in Fig. 7. The soil texture in most cases of the soil samples is medium sandy clay and medium clay loam. The soil $\mathrm{pH}$ values range from 3.6 to 6.5 , while $50 \%$ of the values lie between a $\mathrm{pH}$ of 4.4 and 5. Therefore, most of the soils are acidic, only some cases are near to a neutral $\mathrm{pH}$. In general, an electric conductivity (EC) above $2 \mathrm{dS} / \mathrm{m}$ can potentially have a negative effect on plant growth, and a soil with an EC value above $4 \mathrm{dS} / \mathrm{m}$ is considered saline (Brady and Weil 2002). The EC values of all soil samples are below $0.5 \mathrm{dS} / \mathrm{m}$, which indicates that soil salinity is not present in the surveyed sites. The organic carbon content of the soil samples ranges between 0.38 and $3.08 \%$, while $50 \%$ of all values lie between 1.47 and 1.93 . Total nitrogen ranges from 0.05 to $0.22 \%$. The $\mathrm{C} / \mathrm{N}$ ratio of $50 \%$ of the samples lies between 11.12 and 14.81 .

Available phosphorous ranges between 3.5 and $29 \mathrm{mg} / \mathrm{kg}$ soil, while half of the values lie between 7.14 and $17.69 \mathrm{mg} / \mathrm{kg}$. The phosphorous values of $50 \%$ of the soil samples are below $5 \mathrm{mg} / \mathrm{kg}$.

\section{Occurrence of Accompanying Alien Species}

Habitats of $M$. micrantha are characterized by a large number of alien species, reaching a percentage of $44 \%$ referred to all sample

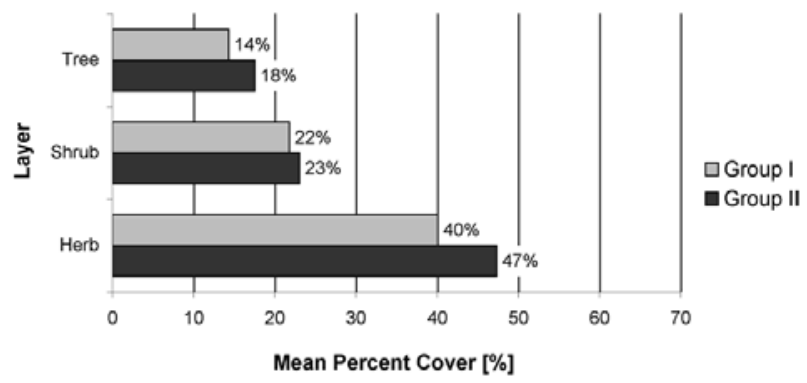

Fig. 6. Mean percent cover of vegetation layers (without Mikania micrantha).
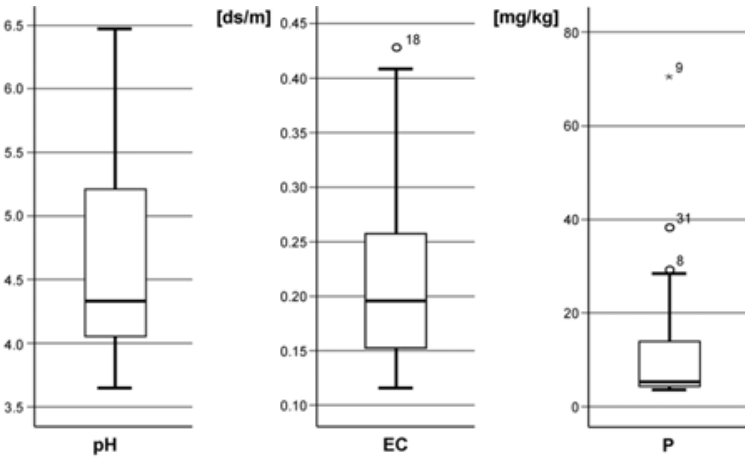

[\%]

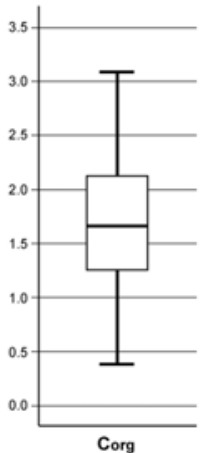

[\%]
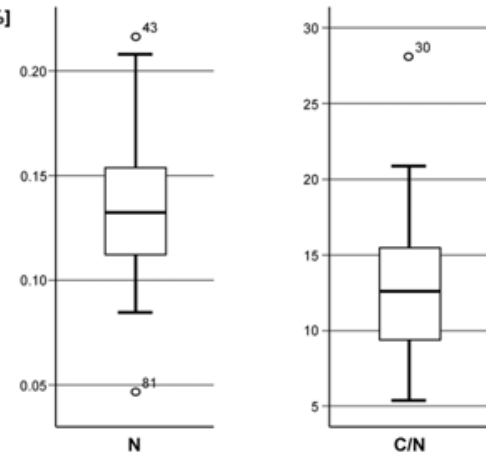

Fig. 7. Box plots of data of soil parameters (line inside box = median, ${ }^{\circ}=$ outlier, $*=$ extreme).

plots. Indigenous species (Asia and Palaeotropis) occur with a frequency of $45.4 \%$, pantropical and cosmopolitan species as well as cultivars were registered separately and they account for almost $5.8 \%$. Species with an uncertain origin attain a percentage of $4.7 \%$ (Fig. 8). The comparison shows that alien and indigenous species attain almost the same frequencies. The major part of alien species originates from America, the second most frequent origin is Africa, and a small percentage of alien species originate from other Asian

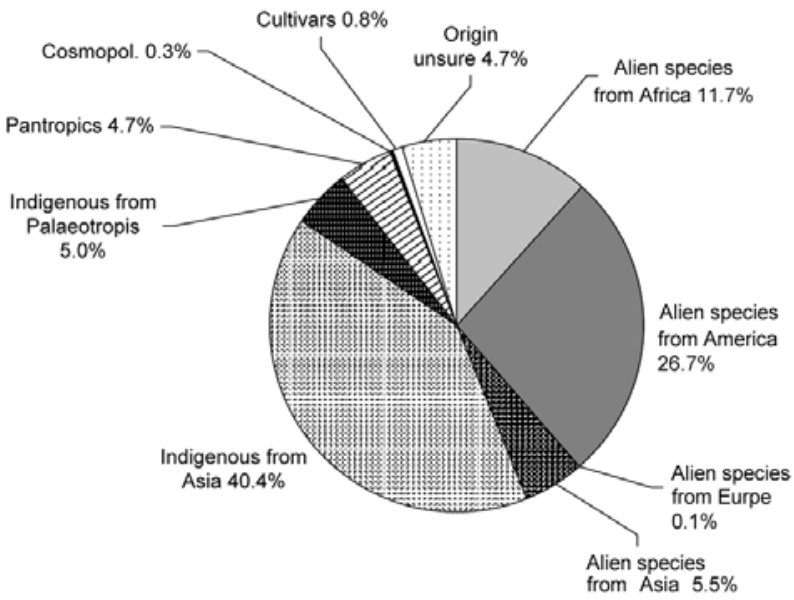

Fig. 8. Percentage of alien species according to their natural distribution area. 
countries. The natural range of most of the indigenous species includes several Asian countries. Only a small number has its distribution throughout the Palaeotropics.

\section{Moisture Indicators}

Species which have been identified as soil moisture indicators are the following vascular plants: Althernanthera sessilis, Anisogonium esculentum, Basella alba, Brachiaria mutica, Commelina diffusa, Cyperus distans, Cyperus imbricatus, Eclipta prostrata, Equisetum ramosissimum ssp. debile, Kyllinga brevifolia, Ludwigia hyssopifolia, Ludwigia octovalvis, Panicum repens, Paspalum conjugatum, Paspalum longifolium, and Scleria terrestris. The analysis of these plants shows that moisture indicators occur slightly more frequently in group I (12.9\%) compared to group II (9.1\%). In 64\% of all sites in group I at least one moisture indicator could be found, in group II there was at least one moisture indicator in $46 \%$ of the sites.

\section{Ecological Characteristics of Indicator Species}

Applying the Mann- Whitney U test, all plant species present in the 112 sample plots were compared between the two M. micrantha abundance groups. Species with a significant difference (Mann-Whitney $\mathrm{U}$ test; $p<0.05$ ) between the groups are: Ipomoea triloba, Macaranga tanarius, Panicum maximum, and Trema orientalis. Two species, I. alba and Passiflora foetida, showed a statistically significant tendency (Mann-Whitney U test; $p<0.08$ ). Ipomoea alba, Macaranga tanarius, and $T$. orientalis occur more frequently in group I (high $M$. micrantha abundance), the other three species were more frequent in group II (low M. micrantha abundance).

The ecological characteristics of species in group I can be summarized as follows: I. alba and Trema orientalis both prefer moist sites on well-drained soil, but the latter species can be found in a wide range of habitats. This also applies to $M$. tanarius. All three species are frequent in disturbed areas. Ecological characteristics of species in group II are: I. triloba occurs in a wide range of habitats, while $P$. maximum and $P$. foetida favor wet areas and more shady conditions. All three species grow well in disturbed habitats.

\section{Assessment of Disturbances.}

The evaluation of the disturbance frequency shows that the majority $(60 \%)$ of those $M$. micrantha sites, which are not abandoned, is exposed to rare disturbances. $40 \%$ of the sites are influenced by frequent disturbances.

\section{DISCUSSION}

\section{Habitat Structure}

We found out that the majority of sites with a high abundance of M. micrantha belongs to herbaceous formations and the herb layer attains on average the highest densities of all layers, illustrating a preference of this alien species for open vegetation formations. In sites with a low abundance of the climber, a high percentage of woody formations can be noticed and the land use categories $\mathrm{F}$ and FE are slightly more frequent there. This shows that the plant grows less densely under shadier conditions. The alien species was not present in dense forest stands; it occurred only along the edge of forests or in clearings. The comparison of ecological characteristics of significant species (indicator species) between the two $M$. micrantha abundance groups also reveals that site conditions in group II (low abundance) are slightly shadier. Similar habitat preferences of $M$. micrantha have also been observed for its native as well as its non-native range of distribution (Holm et al. 1977, Sankaran et al. 2001). These results support the hypothesis that the alien plant grows best in open habitats with good light conditions.

Nevertheless, a significant number of $M$. micrantha habitats is not completely open. One third of all sites in the abundance group I (high abundance) belongs to woody formations, indicating that the plant can as well grow densely in habitats where shrubs and trees are predominant. Although M. micrantha has the ability to rapidly colonize open ground and form dense mats (Holm et al. 1977), it was observed that the climber is less frequent in open habitats with a dense grass layer. In such habitats, M. micrantha attains only punctually a high coverage where vertical structures, such as tall herbaceous species, or medium-sized shrubs and trees, are present. The invader seems to be most competitive with the presence of supporting structures, where it can climb on, thus raising itself out of the herb layer. This observation is supported by the result that habitats along property boundaries are more frequent in sites with a high $M$. micrantha abundance. The characteristic feature of these habitats is a fence, providing an ideal vertical structure for twining plants to climb up. Furthermore, habitats along fences are usually open towards both sides and therefore light is abound. This suggests that M. micrantha develops especially dense populations in locations where supporting structures combined with good light conditions are present. It could also explain why the invader occurs frequently in young tree plantations (Sankaran et al. 2001) and other perennial crop plantations (Holm et al. 1977) throughout Asia.

\section{Soil Conditions}

The analysis of soil samples shows low values for $\mathrm{pH}$ and low contents of total nitrogen as well as organic carbon. These results accord with the general situation of soil conditions in the study area. The average content of soil organic carbon in rural soils of Taiwan is 2\% (Chen and Hseu 1997). In 50\% of the sampled soils, 
the available phosphorous is above $5 \mathrm{mg} / \mathrm{kg}$ soil. A phosphorous content above $5 \mathrm{mg} / \mathrm{kg}$ soil is considered ideal for plant growth (Foth and Ellis 1988). Nevertheless, phosphorous values of half of the soil samples were below $5 \mathrm{mg} / \mathrm{kg}$, and therefore not suitable for plant growth. Altogether, the alien climber grows on soils with rather low fertility and generally acidic reaction in the investigation area. Similar results have been observed in previous studies about M. micrantha in Guangdong province, China (Zhang et al. 2004, Ye and Zhou 2001). This leads to the conclusion that soil conditions are not a crucial factor for the establishment and spread of $M$. micrantha.

It was assumed that the American climber prefers sites with a good soil moisture regime in Taiwan, since this is the case in its native range (Holm et al. 1977). Sankaran et al. (2001) even assume that lack of water may be a limiting factor for the growth of $M$. micrantha. This is supported by the analysis of ecological characteristics of significant plant species (indicator species), which shows that site conditions are rather moist in both $M$. micrantha abundance groups. The assessment of moisture indicators reveals that slightly more soil moisture indicator plants can be found in sites with a high M. micrantha abundance. Nevertheless, the percentage of soil moisture indicators in sites with a low M. micrantha abundance is very similar to that of sites with a high abundance of the plant.

\section{Influence of Disturbances}

The landscape of the lowlands in Pingtung County has been strongly altered by human activities, and only few areas with natural vegetation can still be found (Hsieh and Yang 1994). Therefore, it is not surprising that the majority of M. micrantha habitats within the study area is anthropogenically influenced. Even in the lower mountain regions, the alien plant exclusively occurs in habitats, which are subject to management activities, for example along roadsides and forest margins. These observations support the hypothesis that the American climber can be found frequently in anthropogenically influenced habitats.

The assessment of the disturbance frequency shows that the majority of $M$. micrantha sites (excluding sites of the land use category CNUL) are subject to rare disturbances and less sites are influenced by frequent disturbances. This supports the hypothesis that occasional disturbances further the occurrence of the plant. For example, M. micrantha is second abundant in managed green spaces (MGS). Habitats in this land-use category are usually subject to rare management activities (mowing, cutting), which keep the vegetation open. In between management measures, the climber has the chance to recover. The plant might not grow up into the tree canopy, but it develops dense mats in the herb layer. The invader is also very abundant along property boundaries. Here, the application of her- bicides is the major management measure. In most cases of these habitats, herbicides are regularly applied but not very frequent. The comparison of the frequency of land-use types between areas where M. micrantha is present and where it is absent shows that the plant does not occur in habitats where management measures are carried out very frequently.

This study shows that disturbance seems to be a crucial factor for the establishment and spread of M. micrantha. This generally applies to the growth habits of plant invasions (Mack 1989, Hobbs 1989) and has been observed for M. micrantha in other countries, for example in northern India, where the climber rapidly invades land, which is influenced by fire due to slash-and-burn agriculture (Swamy and Ramakrishnan 1988). Nevertheless, the alien species is only promoted if disturbances occur occasionally.

\section{Influence of the Abandonment of Land}

The assumption that $M$. micrantha is especially abundant in agricultural fallows and wastelands is confirmed by this study, which reveals that the majority of $M$. micrantha habitats belong to the land-use type 'currently not used land' (CNUL). Nevertheless, habitats within this land-use category have, in general, previously been used, which means that some form of disturbance influenced the ecosystem in the past leading to rather open vegetation formations.

The characterization of $M$. micrantha habitats suggests that there is a relationship between the initiation of succession and the occurrence of the climber. M. micrantha illustrates a preference for sites, which have been subject to disturbances in the past, but are currently not used and are characterized by secondary plant succession. The alien plant seems to rapidly colonize habitats in an early successional stage and reaches its highest abundance between an early and a medium successional stage. As succession progresses conditions become shadier and the abundance of M. micrantha slowly decreases (Fig. 9).

It is possible that the invader can establish very well in pioneer communities, which are characterized by a high proportion of ruderals ( $r$-strategists), because there is less competition of other plants (comp. Rejmánek 1989). With the emergence of woody spe-

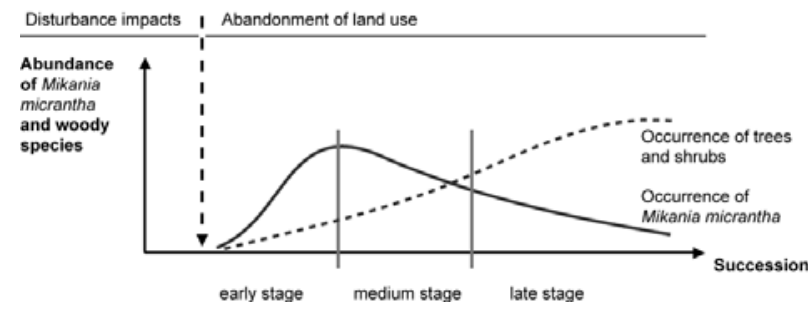

Fig. 9. Model for the abundance of Mikania micrantha during different successional stages. 
cies, M. micrantha seems to attain its maximum cover. These observations are supported by Rejmánek (1989), who states that very often an invasion of non-native species does not have its maximum in the beginning (of a successional series, the author) but increases during the first 5 to 10 years and declines later (Rejmánek 1989: 372). Similar growth characteristics for M. micrantha have been observed during succession in slash-and-burn agriculture in India (Swamy and Ramakrishnan 1988). Only here, the plant reached its peak growth in $4 \sim 5$ years old fallows, but decreased in 8 years old fallow areas.

\section{CONCLUSIONS}

A better understanding of the ecological site conditions of $M$. micrantha is very helpful to predict, which habitats or land-use types are potentially at a higher risk to be invaded by the plant. This study found out that land, which is subject to rare disturbances, or has been subject to disturbances in the past is especially vulnerable to be overgrown by the alien climber. Such habitats are found, for example, in abandoned agricultural plantations, in areas along roads and watercourses, in areas surrounding building grounds, but also in forest clearings or gaps. It is assumed that the plant is less abundant in agricultural plantations, because they are intensely managed. The economic impact of the American climber in Taiwan has not yet been studied in detail, but it is assumed that the majority of agricultural plantations is intensely managed, independent from the presence of the climber. These observations lead to the conclusion that M. micrantha does not pose an economical threat to managed agricultural systems or light-limited forest plantations.

This study concludes that $M$. micrantha was considered an aggressive invader in Taiwan in the beginning of this decade, but the impact of the climber can now be considered minor for the intensively managed land found in Pingtung County. In late successional series, $M$. micrantha does not pose a threat to other plants; it rather occupies a niche within near-natural forest ecosystems. Nevertheless, based on the study of ecological site conditions of $M$. micrantha, general recommendations can be made for the habitat management to prevent a further spread of the alien species in Taiwan. Disturbances, especially the opening of the ground as well as the vegetation cover should be avoided. It is recommended to create shady conditions in tree plantations. Furthermore, it is advised to use groundcover plants in agricultural and silvicultural plantations in order to prevent the establishment of $M$. micrantha.

\section{ACKNOWLEDGMENTS}

The authors especially thank Prof. Dr. Zeng-Yei Hseu and assistants (National Pingtung University of Science and Technology (NPUST), Taiwan) for analyzing the soil samples. Prof. Dr. ShengZehn Yang and assistants (NPUST, Taiwan), as well as Chih-Chung Lin (National Sun Yat Sen University, Taiwan) are kindly acknowledged for their assistance in identifying plant specimens. We gratefully thank Prof. Dr. Chaur-Tzuhn Chen and assistants (NPUST, Taiwan) for providing a workspace in the GIS laboratory of the Department of Forestry, NPUST and for their assistance in the use of ArcMap. Many thanks also to Dr. Arthur Brande (Berlin University of Technology, Germany) for fruitful discussions and valuable suggestions.

\section{LITERATURE CITED}

A Global Compendium of Weeds. 2007. Species search. http://www. hear.org/gcw/alpha_select_gcw.htm. Accessed Jan 2007.

Boufford DE, Hsieh CF, Huang TC, Kuoh CS, Ohashi H, Peng CI, Tsai JL, Yang KC (eds). 2003. A checklist of vascular plants of Taiwan. In: Flora of Taiwan. vol. 6, 2nd edn. (Huang TC, Boufford DE, Hsieh CF, Kuoh CS, Ohashi H, Peng CI, Tsai JL, Yang KC, eds). National Taiwan University, Taipei, pp 15-139.

Brady NC, Weil RR. 2002. The Nature and Properties of Soils, 13th edn. Prentice Hall, Upper Saddle River, NJ.

Braun-Blanquet J. 1964. Pflanzensoziologie. Grundzüge der Vegetationskunde, 3rd edn. Springer Verlag, Wien.

Chen ZS, Hseu ZY. 1997. Total organic carbon pool in soils of Taiwan. Proc. National Sci. Coun. (ROC). Part B: Life Sci 21: 120127.

Chiang MY, Hsu LM, Chen FY. 2002. Confirmation on the presence of Mikania micrantha Kunth in Taiwan. Plant Prot Bull 44: 61-65. (in Chinese)

Clayton WD, Harman KT, Williamson H. 2006 onwards. GrassBase The Online World Grass Flora. http://www.kew.org/data/grassesdb/sppindex.htm. Accessed 10 Jan 2007.

Cook BG, Pengelly BC, Brown SD, Donnelly JL, Eagles DA, Franco MA, Hanson J, Mullen BF, Partridge IJ, Peters M, Schultze-Kraft R. 2005. Panicum maximum. Tropical Forages: an interactive selection tool. CSIRO, DPI\&F(Qld), CIAT and ILRI, Brisbane. http:// www.tropicalforages.info. Accessed 5 Mar 2007.

Cronk QCB, Fuller JL. 1995. Plant Invaders. Chapman and Hall, London.

Danida Forest Seed Centre. 2007. Alstonia scholaris (L.) RBr. Seed Leaflet 9. http://www.dfsc.dk/pdf/Seedleaflets/Alstonia\%20scholaris_ int.pdf. Accessed 9 Jan 2007.

Drake J, Mooney HA, Di Castri F, Groves R, Kruger FJ, Rejmánek M, Williamson M (eds). 1989. Biological Invasions: A Global Perspective. SCOPE 37. John Wiley \& Sons, Chichester.

Duke JA. 1983. Panicum maximum. Handbook of energy crops. http:// www.hort.purdue.edu/newcrop/duke_energy/dukeindex.html. Accessed 5 Mar 2007.

eFloras. 2007a. Flora of China. http://www.efloras.org/flora_page.aspx? flora_id=2. Accessed 25 Jan 2007. 
eFloras. 2007b. Flora of North America. http://www.efloras.org/flora page.aspx?flora_id=1. Accessed 25 Jan 2007.

Ellenberg H, Weber HE, Düll R, Wirth V, Werner W, Paulissen D. 2001. Zeigerwerte von Pflanzen in Mitteleuropa, 3rd edn. Scr geobot 18: 1-262.

Erhardt W, Götz E, Bödeker N, Seybold S (eds). 2000. Zander. Dictionary of Plant Names, 16th edn. Ulmer, Stuttgart.

Federal Noxious Weed Disseminules of the U.S. 2007. Fact sheets. http://www.lucidcentral.org/keys/FNW/Whole\%20key\%20html/Tax alist_factsht.htm. Accessed Jan 2007.

Feng HL, Cao HL, Liang XD, Zhou X, Ye WH. 2002. The distribution of Mikania micrantha in Guangdong. J Trop Subtrop Bot 10(3): 263-270. (in Chinese)

Foth HD, Ellis BG. 1988. Soil Fertility. John Wiley \& Sons, New York, USA.

French JV, Lonard RI, Everitt JH. 2003. Cissus sicyoides C. Linnaeus (Vitaceae), a potential exotic pest in the Lower Rio Grande Valley, Texas. Subtrop Pl Sci 55: 72-74.

Geography of Taiwan. 2001. The climate of Taiwan. http://twgeog.geo. ntnu.edu.tw/english/climatology/climatology.htm. Accessed 26 Feb 2007.

GISD - Global Invasive Species Database. 2006. Mikania micrantha. http://www.issg.org/database/species/ecology.asp?si=42\&fr=1\&sts= tss. Accessed 19 May 2006.

GISP - Global Invasive Species Programme. 2003. Invasive Alien Species - A Growing Global Threat. http://www.gisp.org/ecology/IAS. asp. Accessed 10 Apr 2007.

Hobbs RJ. 1989. The nature and effects of disturbance relative to invasions. In: Biological invasions: a global perspective. SCOPE 37 (Drake J, Mooney HA, Di Castri F, Groves R, Kruger FJ, Rejmánek M, Williamson M, eds). John Wiley \& Sons, Chichester, pp 389-405.

Holm LG, Plucknett DL, Pancho JV, Herberger JP. 1977. The World's Worst Weeds: Distribution and Biology. University Press of Hawaii, Honululu.

Holmes W. 1993. The genus Mikania (Compositae: Eupatorieae) in the Greater Antilles. Botanical Research Institute of Texas, Fort Worth, Tex.

Hsieh CF, Yang KC. 1994. Introduction to the flora of Taiwan, 3: floristics, phytogeography, and vegetation. In: Flora of Taiwan, vol 1, 2nd edn. (Huang TC, Huang CF, Li ZY, Lo HC, Ohashi H, Shen CF, Wang CJ, eds) National Taiwan University, Taipei, p 12.

Hsu LM, Chiang MY. 2003. Comparison of seed germination and vegetative growth of two Mikania species. Plant Prot Bull 45: 321-328.

Hu YJ, But PPH. 1994. A study on life cycle and response to herbicides of Mikania micrantha. Acta Scient Nat Univ Sunyatseni 33: 88-95. (in Chinese)

Huang TC, Boufford DE, Hsieh CF, Kuoh CS, Ohashi H, Peng CI, Tsai JL, Yang KC (eds). 2003. Flora of Taiwan, vol. 6, 2nd edn. National Taiwan University, Taipei.

Huang TC, Boufford DE, Hsieh CF, Kuoh CS, Ohashi H, Su HJ (eds). 2000a. Flora of Taiwan, vol. 5, 2nd ed. National Taiwan University, Taipei.
Huang TC, Boufford DE, Hsieh CF, Ohashi H, Peng CI (eds). 1998. Flora of Taiwan, vol. 4, 2nd ed. National Taiwan University, Taipei.

Huang TC, Hsieh CF, Keng H, Shieh WC, Tsai JL, Hu JM, Shen CF, Yang KC, Yang SY (eds). 1994. Flora of Taiwan, vol. 1, 2nd edn. National Taiwan University, Taipei.

Huang TC, Huang CF, Li ZY, Lo HC, Ohashi H, Shen CF, Wang CJ (eds). 1993. Flora of Taiwan, vol 3, 2nd edn. National Taiwan University, Taipei.

Huang ZL, Cao HL, Liang XD, Ye WH, Feng HL, Cai CX. 2000b. The growth and damaging effect of Mikania micrantha in different habitats. J Trop Subtrop Bot 8(2): 131-138. (in Chinese)

Huang,TC, Boufford DE, Hsieh CF, Ohashi H, Yang YP (eds). 1996. Flora of Taiwan, vol. 2, 2nd edn. National Taiwan University, Taipei.

Hwang SY, Kuo YH, Peng JJ. 2003. The Spread and Monitoring Program for Mikania micrantha in Taiwan. Paper presented at the 2003 WSSROC conference on the harmful effect and field management of Mikania micrantha. Hualien, 8 Dec 2003. http://wssroc. agron.ntu.edu.tw/symposium1/mikania_e.htm. Accessed Aug 2006. (in Chinese)

ICRAF - International Center for Research in Agroforestry. 2007. Macaranga tanarius. Agroforestrytree Database. http://www.worldagroforestrycentre.org/sea/Products/AFDbases/AF/index.asp. Accessed 5 Mar 2007.

IUCN - The World Conservation Union. 2000. IUCN Guidelines for the prevention of biodiversity loss due to biological invasions. http://www.iucn.org/themes/ssc/publications/policy/invasivesEng.htm. Accessed Apr 2007.

Keeney DR, Nelson DW. 1982. Nitrogen - inorganic forms. In: Methods of Soil Analysis, part 2, 2nd ed. (Page et al, eds). Agron. Monogr. 9. Agronomy Society of America and Soil Science Society of America, Madison, WI, pp 643-698.

Knickrehm B, Rommel S. 1995. Biotoptypenkartierung in der Landschaftsplanung. Natur und Landschaft 70(11): 519-528.

Kuo S. 1996. Phosphorus. In: Methods of Soil Analysis, part 3. SSSA Book series No. 5 (Sparks DL, ed). Agronomy Society of America and Soil Science Society of America, Madison, WI, pp 869-919.

Kuo YL, Chen TY, Hwang CW. 2003. Ecophysiological characteristics of Mikania micrantha H.B.K. Paper presented at the 2003 WSSROC conference on the harmful effect and field management of Mikania micrantha. Hualien, 8 Dec 2003. http://wssroc.agron.ntu.edu.tw/ symposium1/mikania_e.htm. Accessed Aug 2006. (in Chinese)

Kuo YL, Chen TY, Lin CC. 2002. Using a consecutive-cutting method and allelopathy to control the invasive vine, Mikania micrantha H.B.K. Taiwan J For Sci 17(2): 171-81.

Mack RN. 1989. Temperate grasslands vulnerable to plant invasions: characteristics and cosequences. In: Biological invasions: a global perspective. SCOPE 37 (Drake J, Mooney HA, Di Castri F, Groves R, Kruger FJ, Rejmánek M, Williamson M, eds). John Wiley \& Sons, Chichester, UK, pp 155-180.

McLean EO. 1982. Soil pH and lime requirement. In: Methods of Soil Analysis, part 2, 2nd ed. (Page AL, Miller RH, Keeney DR, eds). Agron. Monogr. 9. Agronomy Society of America and Soil Science Society of America, Madison, WI, pp 199-224. 
Mooney HA, Hobbs RJ (eds). 2000. Invasive Species in a Changing World. Island Press, Washington, D.C.

Morton JF. 1987. Fruits of warm climates. Julia F Morton, Miami, FL. http://www.hort.purdue.edu/newcrop/morton/index.html. Accessed Jan 2007.

Mueller-Dombois D, Ellenberg H. 1974. Aims and Methods of Vegetation Ecology. John Wiley \& Sons, New York Chichester Brisbane Toronto.

Nelson DW, Sommers LE. 1982. Total carbon, OC, and organic matter. In: Methods of Soil Analysis, part 2, 2nd ed. (Page AL, Miller RH, Keeney DR, eds). Agron. Monogr. 9. Agronomy Society of America and Soil Science Society of America, Madison, WI, pp 539-577.

Nentwig W, ed. 2008. Biological invasions. Ecological Studies 193: 59-74.

NewCROP. 2007. Albizia falcataria. Center for New Crops \& Plant Products, Purdue University. http://www.hort.purdue.edu/newcrop/ default.html. Accessed Jan 2007.

Ng SC, Corlett R. 2002. The bad biodiversity: alien plant species in Hong Kong. Biodiv Sci 10(1): 109-118.

Parker C. 1972. The Mikania problem. Center for overseas pest research. PANS - Pest Articles and News Summaries 18: 312-315.

Perrings C, Williamson M, Barbier EB, Delfino D, Dalmazzone S, Shogren J, Simmons P, Watkinson A. 2002. Biological invasion risks and the public good: an economic perspective. Cons Ecol 6(1): 1. http://www.consecol.org/vol6/iss1/art1. Accessed 10 Apr 2007.

PIER - Pacific Island Ecosystems at Risk. 2007. Plant threats to Pacific ecosystems. Index of all PIER Species. http://www.hear.org/Pier/ scinames.htm. Accessed Jan 2007.

Pimentel D, Lach L, Zuniga R, Morrison D. 2000. Environmental and economic costs of non-indigenous species in the United States. BioScience 50: 53-65.

Pyšek P, Prach K, Rejmánek M, Wade PM (eds). 1995. Plant Invasions General Aspects and Special Problems. SPB Academic Publishing, Amsterdam.

Rejmánek M. 1989. Invasibility of plant communities. In: Biological Invasions: a Global Perspective. SCOPE 37 (Drake J, Mooney HA, Di Castri F, Groves R, Kruger FJ, Rejmánek M, Williamson M, eds) John Wiley \& Sons, Chichester, UK, pp 369-388.

Rhoades JD. 1982. Soluble salts. In: Methods of Soil Analysis. part 2, 2nd ed. (Page AL, Miller RH, Keeney DR, eds) Agron. Monogr.
9. ASA and SSSA, Madison, WI, pp 167-180.

SANBI - South African National Biodiversity Institute. 2007. Panicum maximum. Plants of Southern Africa. http://www.plantzafrica.com/ frames/plantsfram.htm. Accessed 5 Mar 2007.

Sankaran KV, Muraleedharan PK, Anitha V. 2001. Integrated management of the alien invasive weed Mikania micrantha in the Western Ghats. KFRI Resaerch Report No. 202, Kerala Forest Research Institute, Peechi.

Silva EAA, Davide AC, Faria JMR, Melo DLB, Abreu GB. 2004. Germination studies on Tabebuia impetiginosa Mart. seeds. Cerne 10(1):1-9. Available via DIALOG. http://www.dcf.ufla.br/cerne/ rev-v10n1-2004.htm. Accessed Jan 2007.

Starfinger U, Kowarik I, Rode M, Schepker H. 2003. From desireable ornamental plant to pest to accepted addition to the flora? - the perception of an alien tree species through the centuries. Biol Inv 5: 323-335.

Starr F, Starr K, Loope L. 2003. Macaranga tanarius. Plants of Hawai'i Reports. http://www.hear.org/starr/hiplants/reports/index.html. Accessed 5 Mar 2007.

Swamy PS, Ramakrishnan PS. 1988. Effect of fire on growth and allocation strategies of Mikania micrantha under early successional environments. J Appl Ecol 25(2): 653-658.

Taiwan Provincial Mountain Agriculture and Pasture Development Bureau. 1984. Soil Survey Report of Slope Lands in Pingtung. Taichung, Taiwan.

USDA, NRCS. 2007. The PLANTS Database. National Plant Data Center, Baton Rouge, LA 70874-4490 USA. http://plants.usda.gov. Accessed Jan 2007.

Waterhouse DF. 1994. Biological Control of Weeds: Southeast Asia prospects. ACIAR, Canberra, Australia.

Whiffin T. 1973. Analysis of a Hybrid Swarm between Heterocentron elegans and H. glandulosum (Melastomataceae). Taxon 22(4): 413423.

Wu SH, Hsieh CF, Rejmánek M. 2004. Catalogue of the naturalized flora of Taiwan. Taiwania 49(1): 16-31.

Ye WH, Zhou X. 2001. The plant killer - Mikania micrantha in South China. Aliens 13: 7.

Zhang LY, WH Ye, Cao HL, Feng HL. 2004. Mikania micrantha H.B.K. in China - an overview. Weed Research 44: 42-49.

(Received September 15; Accepted November 5, 2008) 


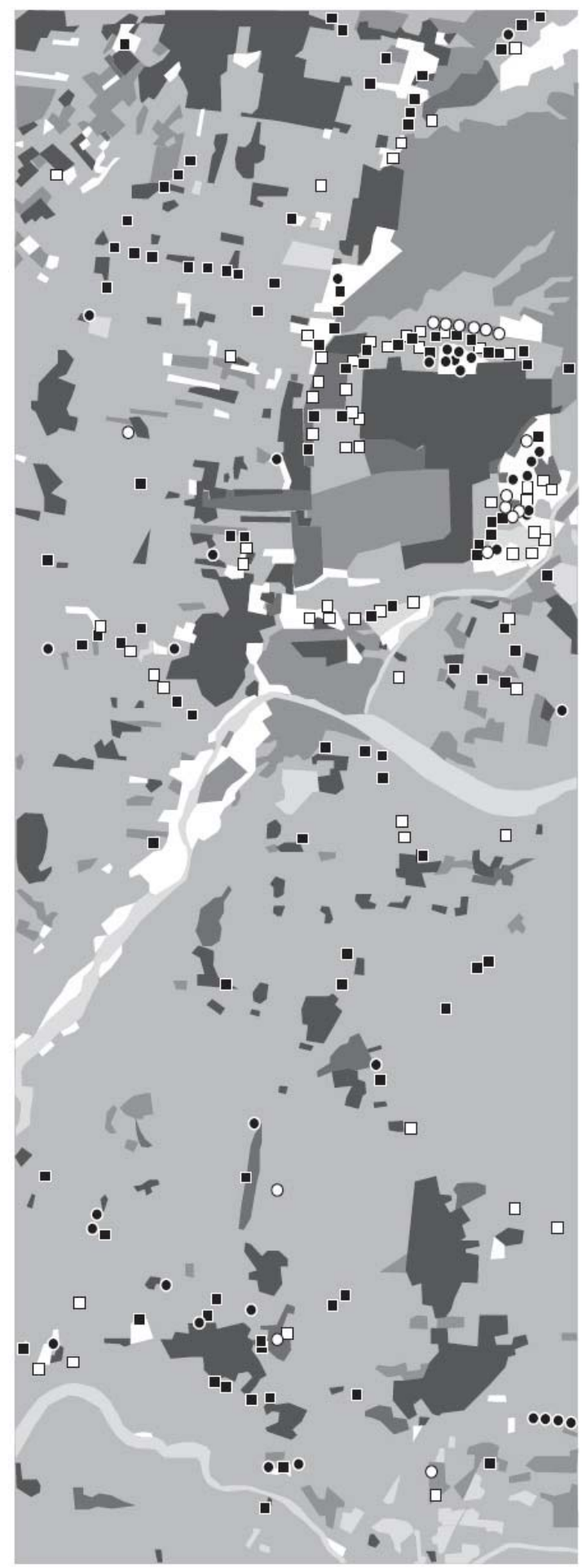

Land use and

Mikania micrantha

occurrences in the

main investigation area

\section{Land use type}

Agricultural plantation (AP)

\section{Agricultural tree} plantation (ATP)

Currently not used land (CNUL)

\section{Managed} green spaces (MGS)

$\square$ Settlement (S)

\section{Water (W)}

\section{Mikania micrantha} occurrences

High abundance

- linear or punctual occurrences

- areal occurrences

Low abundance

$\square \quad$ linear or punctual occurrences

- areal occurrences

Appendix 1. 